\title{
THE IMPORTANCE OF INTERNAL ASPECTS IN QUALITY \\ IMPROVEMENT
}

\author{
Llopis, Juan \\ Tarí, Juan José \\ Department of Business Management \\ University of Alicante \\ Spain \\ P.O. Box 99 \\ 03080 ALICANTE \\ SPAIN \\ E-mail: jj.tari@ua.es
}

Author's details:

Dr. Juan Llopis, Senior Lecturer in Business Management at the University of Alicante, Spain. His Ph. D. dissertation was an analysis of Corporate Culture. His current research include Human Resources and Quality Management.

Dr. Juan José Tarí, Senior Lecturer in Business Management at the University of Alicante, Spain. His Ph. D. dissertation was an analysis of Quality Management. His current research is Total Quality Management.

Word count: 8519 


\title{
THE IMPORTANCE OF INTERNAL ASPECTS IN QUALITY IMPROVEMENT
}

\begin{abstract}
The adoption of ISO 9000 has been justified in terms of the many benefits it generate, although problems may also arise. Such advantages and disadvantages lead to different reasons for seeking certification. Based on these reasons, this paper analyzed the influence of internal motivation for seeking certification with level of quality management and performance in order to determinate whether internal aspects are more important than external aspects. For this purpose, a factor analysis (to identify reasons) and a cluster analysis (to establish significant differences among the groups in order to study the relation between reasons for seeking certification and level of quality management and performance) have been performed on the answers supplied by 106 certified firms in the Alicante area (eastern Spain). It is part of a wider research process, aimed at analyzing quality practices in certified firms by using quality management elements.
\end{abstract}

Keywords: ISO 9000, reasons of certification, internal motivation, performance, quality management, Spain. 


\section{THE IMPORTANCE OF INTERNAL ASPECTS IN QUALITY \\ IMPROVEMENT}

\section{Introduction}

A successful implementation of a quality system may generate, on the one hand, a differentiation, and on the other hand, low costs (Belohlav, 1993; Grant, 1995). In this respect, the adoption of ISO 9000 has been justified in terms of the many internal and external benefits it can generate (Brown, Van der Wiele and Loughton, 1998; Lee, 1998; Quazi and Padibjo, 1998; Casadesús and Heras, 2001; Singels, Ruël and van de Water, 2001; Yahya and Goh, 2001), although problems may also arise (Brown, Van der Wiele and Loughton, 1998; Joubert, 1998; Kanji, 1998; Quazi and Padibjo, 1998; Singels, Ruël and van de Water, 2001; Yahya and Goh, 2001). Nevertheless, with a correct application of the standard the advantages will doubtlessly outweigh the disadvantages.

Internal benefits are related to the internal functioning of organizations (increase in productivity, improvement in efficiency, reduction in costs and waste, ...); external benefits are benefits concerning the organization in relation to its environment (increase in sales and market share, keeping customer relations, finding new customer, increase customer satisfaction, ...). For their part, disadvantages are extra cost for achieving ISO 9000 certification, increase in paper workload, no attention for development of personnel, ... Notice that these benefits and disadvantages, in one way or another, often influence on organization’s performance (Singels, Ruël and van de Water, 2001).

One factor as a possible explanation for performance of an ISO 9000 certified firms are the reasons to apply for ISO 9000 certification. With internal motivation, organization wants to become certified because the members feel the need to do so; 
external motivation means that organizations gain ISO certification out of external pressures (Singels, Ruël and van de Water, 2001).

Depending on each approach, certified firms may obtain different benefits. We, therefore, would like to make clear which are the reasons for seeking ISO 9000 certification and their influence on the performance of organization and their level of Total Quality Management (TQM). For such purpose, it seems necessary to conduct an empirical examination in order to analyze these ideas and conclude by identifying which are the most important aspects (internal or external ones) to improve quality according to the firms studied.

This paper is an attempt to identify and prioritize the reasons firms may have for seeking certification, classify those reasons and try to establish significant differences among the groups thus created in order to determine if those firms seeking certification for internal reasons obtain a higher performance and have a higher commitment towards TQM. For this purpose, according to the review of the literature we have identified 9 reasons for seeking certification (as we reflect in the next section). With the answers supplied by 106 certified firms in the Alicante area (eastern Spain) we used a factor analysis in order to classify them; then we performed a cluster analysis so as to differentiate groups of firms depending on their reasons for certification. By examining the clusters created, we checked the existence of significant differences among the groups in order to verify the influence of internal reasons upon performance and level of TQM. The results are part of a wider research process, aimed at analyzing quality practices in certified firms by using TQM elements. 


\section{Literature review and hypothesis}

Many specific reasons have been advanced in the literature why companies seek certification (Table I). The results of these studies indicate that the reasons may be internal and external, although Jones, Arndt and Kustin (1997) include a third reason, which they call "mixed motivation", and Yahya and Goh (2001) identify these reasons based on Jones, Arndt and Kustin (1997). In this respect, although the reasons leading to seek certification are mainly of an external nature (Carlsson and Carlsson, 1996; Jones, Arndt and Kustin, 1997; Lee, 1998), those firms seeking certification for internal reasons do encounter fewer difficulties to implement ISO 9000 (Yahya and Goh, 2001) and may improve their performance (Jones, Arndt and Kustin, 1997; Singels, Ruël and van de Water, 2001; Yahya and Goh, 2001).

“take in Table I”

As these studies, many researches have been conducted to understand and assess the effectiveness of the ISO 9000 standards in Spain. Casadesús, Giménez and Martí (1998, 1999) studied 288 certified firms in Catalonia. Ferguson, Sánchez and Sierra (1999) analyzed the characteristics of 51 ISO 9000 certified firms in the province of Cadiz. Martínez et al. (1999) analyzed 77 firms given ISO 9000 certification by the Spanish Association for Normalization and Certification (AENOR) and Escanciano (2000) and Escanciano, Fernández and Vázquez (2001) studied 749 ISO 9000 certified firms in Spain.

These authors point out that reasons for certification (Table II) may be of an internal or an external nature. Amongst them, in most of the firms studied certification has been a result of external reasons, rather than internal ones, and therefore 
certification is actually a marketing strategy (Casadesús, Giménez and Martí, 1998, 1999; Martínez et al., 2000). However, the norm is also accompanied by an improvement in internal organization (Casadesús, Giménez and Martí, 1998, 1999). In this respect, when certification is due to customer requirements, the firm does not fully profit from the system, whereas in those firms where certification stems from a management initiative, the purpose is to improve efficiency and profits are obtained (Martínez et al., 1999). Therefore, reasons exert an influence upon a firm’s performance (Escanciano, Fernández and Vázquez, 2001).

\section{“take in Table II”}

The common reasons in the papers we have reviewed (Tables I and II) are the following: on the one hand, the desire to create a quality culture, reducing costs and defects, improving products, improving efficiency and starting on the right path towards total quality (internal reasons), on the other, improving corporate image, gaining competitive advantage, customer requirements and the possibility to enter new markets (external reasons). In this research we have measured the reasons for seeking certification by these common reasons. These indicators are based on a literature review (Tables I and II) and interviews with managers (as we point out in the next section).

Although it must be taken into account that ISO 9000 certification may be an initial step towards total quality (Askey and Dale, 1994; Bradley, 1994; Stephens, 1994; Meegan and Taylor, 1997; Van der Wiele, Dale and Williams, 1997; Brown, Van der Wiele and Loughton, 1998; Kanji, 1998; Quazi and Padibjo, 1998; McAdams and McKeown, 1999), it alone will not contribute much to quality improvement (Meegan and Taylor, 1997). In this sense, if ISO 9000 series quality system certification is seen 
as a means of improving internal efficiencies, the outcome is more likely to be a workable system. If it is only a reaction to external pressure from customers, it would be more difficult to perceive improvements coming from the quality system (Brown, Van der Wiele and Loughton, 1998; Martínez et al., 1999). Therefore, although some authors suggest that the reason for seeking certification is not a significant factor in determining whether the overall benefits outweigh cost or not (Leung, Chan and Lee, 1999), in general, firms certified due to internal reasons obtain higher profits than those which do so due to external reasons (Lee, 1995; Jones, Arndt and Kustin, 1997; Singels, Ruël and van de Water, 2001; Yahya and Goh, 2001). This leads us to our first hypothesis:

Hypothesis 1: Firms certified due to internal reasons obtain higher profits than those certified due to external reasons.

In this context, firms certified due to internal reasons experienced a relatively lower degree of difficulty in satisfying the elements of ISO 9001 than those certified due to external reasons (Martínez et al., 1999; Yahya and Goh, 2001), and therefore possess a higher quality management culture than those firms certified for external reasons (Jones, Arndt and Kustin, 1997).

Therefore, it is normal that firms more committed to internal reasons show a higher degree of implementation of components of quality management. In this case, the stronger implementation of its elements, the higher the TQM performance (Ahire, Waller and Golhar, 1996; Rao, Raghunathan and Solis, 1999; Rahman, 2001). Thus, we suggest the following hypothesis: 
Hypothesis 2: Firms certified due to internal reasons are those having implemented to a higher degree the elements of quality management.

Building on the previous ideas, human aspects are the least implemented ones (Moreno, 1993; Herrera, Moreno and Martínez, 1998; Martínez, Balbastre and Escrig, 2001); however, a higher commitment towards these aspects may give the firm higher profits and a higher level of TQM. Therefore, firms showing concern for internal aspects are more likely to progress towards quality management (Taylor and Meegan, 1997; Brown, Van der Wiele and Loughton, 1998; Escanciano, Fernández and Vázquez, 2001). Thus, our hypothesis is the following:

Hypothesis 3: When a company is certified due to internal reasons it is more likely to progress towards TQM than when is due to external ones.

Indeed, there are studies proving that firms which have been working for a longer time with certified quality systems obtain higher profits than those that have just been certified (Brecka, 1994; Ferguson, Sánchez and Sierra, 1999), whereas other studies prove that a sizeable number of certified firms do not profit significantly from the certification process, and this situation does not improve over time (Jones, Arndt and Kustin, 1997; Leung, Chan and Lee, 1999; Casadesús and Heras, 2001). This is the problem leading to our fourth hypothesis:

Hypothesis 4: Longer-certified companies perceived greater benefits than recently-certified companies. 
Finally, it might be questioned if the reasons are the same for all firms. Although it may seem that small firms have a significantly more negative attitude towards certification than medium and large firms, there is no clear evidence that the reasons for certification are different (Bryde and Slocock, 1998; Martínez et al., 1999). Thus, we intend to validate the following hypothesis:

Hypothesis 5: There is no association between organization size and reasons for certification.

\section{Research and methodology}

Sample. In order to achieve our objective, and within the wider analysis we mentioned in the introduction, we selected as the population for our study those firms carrying out their activity in the Alicante area (eastern Spain) which have received the ISO 9000 certificate, between the moment the certification process started in this area (1993) and February 1999. In this way, the total population (number of certificates) was 175 . However, we decided eliminate two multinational consultancy firms which were not included in the study because of their characteristics. In addition to this, it was detected that there were four firms with more than one certificate, and therefore all these cases (nine) were regarded as four firms (four answers), for the quality management tasks were performed by one person. Similarly, it was observed that in some firms with different certificates, belonging to the same group, the same person was responsible for the quality activities, and therefore, there was one single, valid interview for all of them; this led us to consider it as one single 
answer, and one single firm (22 certificates corresponding to eight answers). After these considerations, the actual number of firms in the population was 154 .

After finishing the data collection from the 154 firms (October 1999), twelve of them were impossible to obtain, and thus the final population considered was 142, the number of answers being 108, which represents a percentage of 76.06\%. However, two answers were not regarded as valid due to incomplete data; therefore, the number of cases processed statistically with the SPSS software was 106 firms. In this respect, the characteristics of these 106 firms (industrial and services sector) are those shown in Table III.

\section{"take in Table III"}

The reason why we selected certified firms is because we wanted firms with some kind of quality system. In this respect, organizations with ISO 9000 series registration would be firms with a first level of TQM (Dale and Lascelles, 1999; Van der Wiele, Williams and Dale, 2000a) and this is an objective criterion guaranteeing that these firms do possess a quality system. Also, the ISO 9000 quality management system, as the excellence models, is improving the understanding of concepts and practices associated with TQM (Van der Wiele, Dale and Williams, 2000, Van der Wiele, Williams and Dale, 2000b), with may help to understand the questions asked.

Data collection. While the database was being selected, the questions were designed (based on Tables I and II as we mentioned in the review of the literature) to meet the objectives that had been set. With these questions we attempted to find out about the reasons for seeking ISO 9000 certification. 
The process of developing the questionnaire finished with a pilot survey, which was used to modify and eliminate variables, until the final questionnaire was designed. Experts on the subject were consulted (an academic, a small-medium firm manager and two quality consultants), to ensure that the questions were properly phrased, and the suitability of the questionnaire was tested on a sample of 10 firms selected at random (Madu, 1998), which allowed us to modify and delete some variables.

The data were collected by means of a structured personal interview, carried out face to face, based on a closed questionnaire, plus a set of open questions which allowed us to clarify certain points. In this way, the process started with a pilot test in June 1999, which allowed us, as has been discussed before, to modify the initial questionnaire; between June and October 1999 we conducted the interviews with the 108 firms that agreed to participate. The questionnaire was answered by the persons in charge of the quality area, for these reasons: a) these persons play an active role in the quality strategy; b) they possess the knowledge required to answer the questionnaire, and given their training and knowledge on the subject, considering that these firms had quality systems, this would allow a better understanding of the questions; and c) in similar studies (Carlsson and Carlsson, 1996; Ferguson, Sánchez and Sierra, 1999; Escanciano, 2000; Escanciano, Fernández and Vázquez, 2001), the key person to interview is the quality manager.

Variables. Starting from here, our measurement instrument is based on a review of the literature. We selected the variables considering the reasons defined by authors in Table I and II. In order to measure these reasons, 9 variables were used in the final questionnaire as has been discussed before (literature review and hypothesis section), measured in a 7point scale. Also, we need other variables in order to assess the elements of TQM and the TQM performance. We use, on the one hand, quality planning, suppliers, customers and 
process management, and continuous improvement (technical elements) and leadership, employee management and learning (human aspects) to measure the TQM elements, and on the other, the TQM performance construct used by Powell (1995), but with one less item to measure TQM performance. These variables were measured in a 7-point scale and can be used to establish their connection between the reasons for seeking certification, and therefore accept or refute the hypotheses formulated.

Analytic procedures. Firstly, we develop a factor analysis with the set of 9 items in order to identify the more important reasons for seeking ISO 9000 certification, based upon the perceptions of quality managers of firms with quality systems. Secondly, we performed a cluster analysis based upon the factors identified in previous analysis.

\section{Results}

Importance of the reasons for certification

From the average scores obtained for the 9 reasons identified in the answers given by the 106 firms studied, the quality image offered to the market has been most valued, followed by improving the firms' control and efficiency, improving product quality and believing that certification would allow an advantage over competitors, whereas reasons such as customer requirements and taking initial step towards total quality have been considered the least important, which proves that many firms do not see ISO 9000 certification as a step towards total quality (Table IV).

"take in Table IV" 
This indicates that both the quality image and its effects upon competition (external factors) and efficiency (an internal factor) are the most important issues, which means that quality is not only motivated by external factors.

\section{Principal component factor analysis}

By performing a principal component factor analysis on these data, it is our intention to group these 9 reasons into others replacing the original variables with the least information being lost. For this purpose the following analysis have been performed: a) the correlation matrix determiner, b) Kaiser-Meyer-Olkin (KMO) measure of sampling adequacy and c) Bartlett's Test of Sphericity. Once these tests have been carried out, we can verify that the data matrix is adequate to perform the principal component factor analysis because the requirements are met (Determiner $=$ 0.158; KMO = 0.696; Bartlett's Test of Sphericity, $\mathrm{p}=0.000$ ).

In order to extract the factors, we take those eigenvalues higher than one, which account for $60 \%$ of the total variance, obtaining three factors. We have performed a varimax rotation on the component matrix for an easier interpretation and a simpler explanation of the factors, ignoring in its representation those factor loads below 0.4 (Huarng, Horng and Chen, 1999) as can be seen in Table V.

\section{“take in Table V"}

From a different point of view, if we apply an a priori criterion to extract the factors, a review of the literature leads us to consider two factors, internal and external ones. Thus, by considering two factors a priori, we obtain two factors from the factor analysis, one internal and another external, which would account for $48 \%$ of the 
variance, i.e. a percentage lower than $60 \%$; therefore, we consider that selecting three factors is more suitable from a statistical point of view. These results prove the need to take into account different criteria in order to decide the number of factors that are maintained.

The following step in the analysis would be interpreting the factors. Thus, Factor 1 would include internal reasons, and therefore would be called internal factor; Factor 2 including external reasons, will be labelled external factor. Finally Factor 3 will be called customer requirements. Thus, we have found three reasons for seeking certification: internal ones, external ones and those due to customer requirements. We include within the first category those firms implementing the ISO 9000 standard because they consider the beneficial effects upon efficiency; in the second group we can find those firms which voluntarily seek certification, but rather than due to internal reasons, they do so because they have observed the effects that certification may have upon the market, by improving their image and competitiveness; this may cause them to increase their market share and, in some cases, anticipate potential future customer demands.

Finally, we have identified firms in which certification has been imposed by their customers; interestingly enough, those firms do not observe positive effects upon efficiency, as can be seen by the negative score in the third factor. Such factor indicates that this dimension has higher loads concerning certification due to customer requirements and lower scores in internal efficiency, which means that firms seeking certification due to customer requirements do not have a high appreciation of the positive effects upon firm efficiency; this, in turn, proves that these firms do not fully profit from the potential of ISO 9000, and therefore their quality level will be low and they will not wish to advance towards total quality. This situation may be verified later 
by means of a cluster analysis.

Among these three reasons, external ones are the most important for seeking certification, considering that for many there are internal reasons, although costs may not be disregarded. In addition to this, although customer requirements are an essential factor leading to this decision, they are not as important as the other reasons (Table VI). These three reasons may be grouped into voluntary certification (factors 1 and 2) and compulsory certification (factor 3).

"take in Table VI"

\section{Cluster analysis}

By applying this analysis, our aim is to group firms according to their reasons for seeking certification. For this purpose, firstly a hierarchical method is used (Ward's method to minimize differences within the clusters and the square euclidean distance) so as to identify the suitable number of groups; then, a non-hierarchical method is applied and validated through the analysis of variance of one factor (Punj and Stewart, 1983; Hair et al., 1995; Ketchen and Shook, 1996).

In order to select the group in the hierarchical method, we have considered the dendogram and the change in agglomeration coefficient. After studying the dendogram we can identify from a minimum of two groups (less homogeneous) to a maximum of four groups (more homogeneous); regarding the agglomeration coefficient, the most important changes occur between two and four groups. Also, the highest difference among percentages of change occurs in three clusters; therefore, three would be the number of groups according to this criterion (Table VII). This method is a very accurate one, although it tends to indicate very few clusters (Hair et al., 1995). 
“take in Table VII”

The number of groups can also be determined by using Fisher's F statistical criterion. In this way, by considering three clusters in the K-means analysis (nonhierarchical) and validating it with Fisher's F statistical criterion, all three factors are significant, whereas for two groups two of the three factors are not significant. Therefore, the best choice statistically speaking is three homogeneous groups which are different from one another. Thus, in order to decide the number of clusters, we may combine different methods. Hence, we consider three groups which are used for the non-hierarchical analysis, and we apply a K-means cluster analysis; the study is validated by analyzing the variance of one factor as we observe that they all three factors are significant (factor $1, \mathrm{p}=0.000$; factor 2 , $\mathrm{p}=0.021$ and factor $3, \mathrm{p}=0.000$ ).

The following stage is the interpretation of the three resulting clusters, also analyzing the differences existing among them in order to verify the hypotheses suggested as we reflect in the next section (Table VIII).

\footnotetext{
"take in Table VIII"
}

The first group is formed by firms which attach the greatest importance to the first factor, i.e. those where internal reasons are the most important for seeking certification; however, this does not imply that such is the only reason, since such firms do not ignore external factors, as can be seen by the value attached to this factor. The fact that this group is the largest proves the importance of these reasons. 
The second group includes those firms which do not seek certification as a result of their customers' requirements; there are both internal and external reasons, which have intermediate scores compared to the other two groups. This proves that they see certification as a way to improve their competitiveness, which can result in internal benefits, and not because there is strong customer pressure.

The third group includes those firms which most highly value the third factor (customer requirements) and yield lower scores than the first one (internal reasons). These are firms seeking certification due to external pressure, and it might seem logical to think that, at least at an initial stage, they do not perceive any internal benefits from certification.

\section{Discussion}

The empirical analysis has identified three groups of reasons for seeking certification (internal reasons, external reasons and due to customer requirements) which, in turn, may be grouped into external and internal reasons, as shown by the literature (Carlsson and Carlsson, 1996; Casadesús, Giménez and Martí, 1998, 1999; Ferguson, Sánchez and Sierra, 1999; Escanciano, Fernández and Vázquez, 2001; Singels, Ruël and van de Water, 2001; Yahya and Goh, 2001). Amongst those reasons, external ones are the most important for many firms, which coincides with other studies reaching the same conclusion (Carlsson and Carlsson, 1996; Casadesús, Giménez and Martí, 1998, 1999; Huarng, Horng and Chen, 1999; Martínez et al., 1999, 2000; Najmi and Kehoe, 2000). This seems to indicate that for some firms certification is mainly a marketing strategy (Casadesús, Giménez and Martí, 1998, 1999; Quazi and Padibjo, 1998). 
Nevertheless, part of the literature shows the opposite case, where internal reasons are the most important ones leading to certification (Idris, McEwan and Belavendram, 1996; Najmi and Kehoe, 2000); such is the opinion of some of the firms studied, as can be seen in Table VIII. This seems to suggest that there are no clear differences between these two groups of reasons, as concluded by Yahya and Goh (2001). Therefore, the importance of the reasons for seeking certification depends on the degree of managerial commitment towards internal aspects.

In this process, managers may be supported by external consultants, which are important for most firms, since $80 \%$ of the firms implement ISO 9000 with the participation of external advisors, and for $39 \%$ of the firms this cooperation continues in the follow-up stage. These results are similar to those obtained by Casadesús, Giménez and Martí (1998, 1999) and Casadesús and Heras (2001), who point out that more than $80 \%$ of firms have resorted to the services of a consultant in the implementation stage.

\section{Hypothesis 1: Relation between reasons and performance}

ISO 9000 certification generates internal and external benefits, but also a number of disadvantages for some firms, which are related to the reasons for certification. In our research, those firms most concerned about internal issues are those obtaining higher profits, as shown by the average scores of the three groups and significant differences among the groups (Table IX).

"take in Table IX"

This leads us, on the one hand, to accept our first hypothesis, and on the other, to support other studies indicating that it is only normal that those firms obtaining higher 
profits should be those seeking certification for internal reasons (Lee, 1995; Jones, Arndt and Kustin, 1997; Brown, Van der Wiele and Loughton, 1998; Singels, Ruël and van de Water, 2001; Yahya and Goh, 2001).

Nevertheless, other authors have remarked that the reasons for seeking certification are not a significant factor in determining whether the overall benefits outweigh cost or not (Leung, Chan and Lee, 1999). Therefore, we may conclude that, barring exceptions, certification based on an internal motivation usually has a positive effect upon a firm’s performance.

\section{Hypothesis 2: Relation between reasons and TQM elements}

Certification based on internal reasons allows firms to obtain higher profits (hypothesis 1) and also to improve their efficiency (Martínez et al., 1999; Yahya and Goh, 2001). This causes firms certified for internal reasons to show a wider implementation of the elements of TQM.

As shown by the averages of the three clusters and significant differences among the groups (Table IX), the higher the concern for internal reasons, the higher the implementation of elements of quality management (technical and the human aspects), which validates our second hypothesis. Therefore, those firms more concerned about internal aspects have a higher level of TQM, as can be observed from the results of other studies (Jones, Arndt and Kustin, 1997; Martínez et al., 1999; Yahya and Goh, 2001).

Hypothesis 3: Relation between reasons and progress towards TQM

The group of firms seeking certification for internal reasons will be those most likely to progress towards TQM. The average group scores in Table IX prove that firms 
implementing quality systems mainly due to internal reasons are those most likely to progress towards total quality, with significant differences among the clusters, which leads acceptance of the third hypothesis. These results coincide with the conclusions obtained by other similar studies (Taylor and Meegan, 1997; Brown, Van der Wiele and Loughton, 1999; Escanciano, Fernández and Vázquez, 2001).

\section{Hypothesis 4: Relation between time and performance}

Building on the previous concepts, we may analyze if the fact that the firm has been certified for a longer time is related to such higher profits. Thus, such higher implementation of the elements of quality management and higher concern about the firm's internal aspects may increase with time, as proved by some of the studies we have mentioned before. In this respect, the analysis show that there are no significant differences among firm clusters depending on how long they have been certified for. Therefore, we refute the fourth hypothesis, which coincides with the results obtained by other authors (Jones, Arndt and Kustin, 1997; Leung, Chang and Lee, 1999; Casadesús and Heras, 2001). This confirms the absence of progressive improvement with time and contradicts previous research (Brecka, 1994; Ferguson, Sánchez and Sierra, 1999) which estimated that the benefits of certification increase with time.

Thus, it seems that there are cases where the benefits of certification increase with time, and other cases where this does not happen. Therefore, both situations may occur, and managers should concentrate on internal aspects in order to increase the likelihood of obtaining profits. 
Hypothesis 5: Relation between reasons and size

Finally, when analyzing the differences between the operations for certification between firms according to their size, it can be verified that there are no significant differences. Such results indicate that firms have the same reasons for certification regardless of their size, which validates our fifth hypothesis. Similarly, there are no significant differences between industrial and service sector firms (Table X).

“take in Table X”

These results verify other studies which pointed out that there is no association between organization size and reason for certification (Bryde and Slocock, 1998; Martínez et al., 1999), but also contradict others which concluded that those firms obtaining less profit were smaller ones (fewer than 50 employees) (Ferguson, Sánchez and Sierra, 1999).

The results seem to strengthen the idea that ISO 9000 certified firms do not have a strong focus on internal aspects, as shown by other studies (Moreno, 1993), but a correct implementation of ISO 9000 may improve their performance, as proved by Martínez et al. (1999) and Singels, Ruël and van de Water (2001).

\section{Conclusions}

The empirical research has identified three factors for seeking certification, called internal reasons, external reasons (voluntary certification) and reasons due to customer requirements (compulsory certification). In the case of voluntary certification, either because ISO 9000 is regarded as beneficial to the firm (mainly due to quality image and competitive advantage) or because there is a wish to create a quality 
awareness within the corporation (internal reasons), it must be thought that such certification is to be considered as part of a wider programme aimed at improving quality, thus increasing productivity and internal efficiency. As for compulsory certification, it may be thought that in the long term it may imply a quality commitment and a favourable atmosphere for such development, followed by a potential implementation of a quality management system, which would justify a positive effect.

By performing a cluster analysis on these factors, the results show that, those firms which attached a greater importance to efficiency do not ignore its positive effects as seen by customers, and those seeking certification due to external reasons do recognize its positive effects upon the firm's efficiency, and those firms seeking certification due to customers' requirements are those where such certification has the least positive influence upon efficiency.

Starting from here, we have proved that firms most concerned about internal reasons are: a) those which most obtain higher profits deriving from the implementation of the quality system; b) those in which there is a greater implementation of elements of TQM, and c) those which are most likely to progress towards total quality. Also, we have confirmed that there is no relation between time and performance and between size and reasons. However, as there is different opinions in the literature in both senses, the fact that a firm has been certified for a long time may or may not have a positive influence upon its profits, and firm size may or may not result in a higher concern for internal aspects.

The results have a number of implications for managers. Firstly, if they desire an improvement of quality throughout the firm, they must show a higher concern for internal aspects (management and employee commitment, training for a higher number of employees, ...) as a way to improve the degree of implementation of TQM elements, 
thus increasing their level of TQM and, as a result, increasing their profits. Also, for time to be a positive factor in increasing the likelihood of higher profits, the commitment towards internal aspects is again a necessary condition. This proves that internal aspects are more important than external ones when it comes to improving quality.

Finally, this paper has focused on the relationship between internal reasons for seeking certification and a firm's performance, thus supplementing the literature on the subject. We have used the relationship between the reasons for certification and the degree of implementation of TQM elements as a way to prove that a higher concern for internal aspects leads certified firms to a wider implementation of TQM elements, something that has not been specifically analyzed in the literature. However, a possible limitation of our study is that it is based on firms from a specific area in Spain, which may make it difficult to extrapolate the result. Therefore, for future research it might be interesting to analyze which internal aspects are more important in order to obtain a higher level of TQM and higher profits by studying firms of different sizes and from various sectors, and also to carry out such study at a national and an international level, in order to overcome the main limitation of this analysis.

\section{References}

AHIRE, S. L.; WALLER, M. A. and GOLHAR, D. Y. (1996), “Quality management in TQM versus non-TQM firms, an empirical investigation”, International Journal of Quality \& Reliability Management, Vol. 13, No. 8, pp. 8-27.

ASKEY, J. M. and DALE, B. G. (1994), "From ISO 9000 series registration to total quality management, an examination”, Quality Management Journal, July, pp. 6776.

BELOHLAV, J. A. (1993), “Quality, strategy and competitiveness”, California Management Review, Vol. 35, No. 3, pp. 55-67.

BRADLEY, M. (1994), "Starting total quality management from ISO 9000”, The TQM Magazine, Vol. 6, No. 1, pp. 50-54.

BRECKA, J. (1994), "Study finds that gains with ISO 9000 registration increase over time”, Quality Progress, May, p. 18. 
BROWN, A., Van der WIELE, T. and LOUGHTON, K. (1998), "Smaller enterprises' experiences with ISO 9000", International Journal of Quality \& Reliability Management, Vol. 15, No. 3, pp. 273-285.

BRYDE, D. and SLOCOCK, B. (1998), "Quality management systems certification: a survey”, International Journal of Quality \& Reliability Management, Vol. 15, No. 5, pp. 467-480.

CARLSSON, M. and CARLSSON, D. (1996), “Experiences of implementing ISO 9000 in Swedish industry", International Journal of Quality \& Reliability Management, Vol. 13, No. 7, pp. 36-47.

CASADESÚS, M. and HERAS, I. (2001), "La norma ISO 9000: beneficios de su introducción en las empresas españolas. Un estudio empírico”, Revista Europea de Dirección y Economía de la Empresa, Vol. 10, No. 1, pp. 55-68.

CASADESÚS, M.; GIMÉNEZ, G. and MARTÍ, R. (1998), "La normativa de aseguramiento de la calidad ISO 9000 en Cataluña: expectativas y efectos. Estudio empírico", Proceeding of the VIII National Congress of ACEDE, September, Las Palmas de Gran Canaria.

CASADESÚS, M; GIMÉNEZ, G. and MARTÍ, R. (1999), “Tipología de empresas certificadas según la normativa ISO 9000. Análisis de los resultados de un estudio empírico”, Proceeding of the IX National Congress of ACEDE, September, Burgos.

DALE, B. G. and LASCELLES (1999), "Levels of TQM adoption", in DALE, B. G. (Ed.), Managing quality, Blackwell Publishers, Oxford.

ESCANCIANO, C. (2000), “La certificación ISO 9000 en España”, Proceeding of the $X$ National Congress of ACEDE, September, Jaen.

ESCANCIANO, C.; FERNÁNDEZ, E. and VÁZQUEZ, C. (2001), "Influence of ISO 9000 certification on the progress of Spanish industry towards TQM", International Journal of Quality \& Reliability Management, Vol. 18, No. 5, pp. 481-494.

FERGUSON, M. C.; SÁNCHEZ, A. and SIERRA, C. (1999), “Análisis de los sistemas de gestión de la calidad según la normativa ISO 9000 en las empresas de la provincia de Cádiz", Proceeding of the IX National Congress of ACEDE, September, Burgos.

GRANT, R. M. (1995), Contemporary strategy analysis: concepts, techniques, applications, Blackwell, Cambridge, Massachusetts.

HAIR, J. F.; ANDERSON, R. E.; TATHAM, R. L. and BLACK, W. C. (1995), Multivariate data analysis with reading, Prentice Hall, Englewood Cliffs, NJ.

HERRERA, J.; MORENO, M. D. and MARTÍNEZ, C. (1998), "La gestión de la calidad en las empresas españolas. Resultados de un estudio empírico de ámbito europeo”, Revista de Economía y Empresa, Vol. 12 (2ª́poca), No. 32, pp. 83-116.

HUARNG, F.; HORNG, C. and CHEN, C. (1999), "A study of ISO 9000 process, motivation and performance”, Total Quality Management, Vol. 10, No. 7, pp. 10091025.

IDRIS, M. A.; McEWAN, W. and BELAVENDRAM, N. (1996), "The adoption of ISO 9000 and total quality management in Malaysia”, The TQM Magazine, Vol. 8, No. 5, pp. 65-68.

JONES, R.; ARNDT, G. and KUSTIN, R. (1997), "ISO 9000 among Australian companies: impact of time and reasons for seeking certification on perceptions of benefits received”, International Journal of Quality \& Reliability Management, Vol. 14, No. 7, pp. 650-660.

JOUBERT, B. (1998), "ISO 9000: international quality standards”, Production and Inventory Management Journal, Vol. 39, No. 2, pp. 60-65. 
KANJI, G. K. (1998), “An innovative approach to make ISO 9000 standards more effective”, Total Quality Management, Vol. 9, No. 1, pp. 67-78.

KETCHEN, D. J., Jr. and SHOOK, C. L. (1996), “The application of cluster analysis in strategic management research, an analysis and critique”, Strategic Management Journal, Vol. 17, No. 6, pp. 441-458.

KRASACHOL, L.; WILLEY, P. C. T. and TANNOCK, J. D. T. (1998), “The progress of quality management in Thailand”, The TQM Magazine, Vol. 10, No. 1, pp. 4044.

LEE, T. (1995), “The experience of implementing ISO 9000 in Hong Kong”, Asia Pacific Journal of Quality Management, Vol. 4, No. 4, pp. 6-16.

LEE, T. Y. (1998), "The development of ISO 9000 certification and the future of quality management: a survey of certification firms in Hong Kong”, International Journal of Quality \& Reliability Management, Vol. 15, No. 2, pp. 162-177.

LEUNG, H. K. N.; CHAN, K. C. C. and LEE, T. Y. (1999), "Cost and benefits of ISO 9000 series, a practical study", International Journal of Quality \& Reliability Management, Vol. 16, No. 7, pp. 675-690.

MADU, C. N. (1998), “An empirical assessment of quality, research considerations”, International Journal of Quality Science, Vol. 3, No. 4, pp. 348-355.

MARTÍNEZ, C.; BALBASTRE, F. and ESCRIG, A. B. (2001), "La evaluación en el marco de la gestión de la calidad: un análisis en función del enfoque utilizado", Revista Europea de Dirección y Economía de la Empresa, Vol. 10, No. 1, pp. 37-54.

MARTÍNEZ, C.; BALBASTRE, F.; ESCRIBÁ, M. A.; GONZÁLEZ, T. and PARDO, M. (1999), "Análisis de la implantación de un sistema de aseguramiento de calidad en base a normas ISO 9000”, Proceeding of the IX National Congress of ACEDE, September, Burgos.

MARTÍNEZ, C.; BALBASTRE, F.; ESCRIBÁ, M. A.; GONZÁLEZ, T. and PARDO, M. (2000), "Aspectos clave del proceso de implantación de un sistema de aseguramiento de la calidad”, Proceeding of the XIV National Congress of AEDEM, June, Jaen.

McADAM, R. and McKEOWN, M. (1999), "Life after ISO 9000, An analysis of the impact of ISO 9000 and total quality management on small businesses in Northern Ireland”, Total Quality Management, Vol. 10, No. 2, pp. 229-241.

MEEGAN, S. T. and TAYLOR, W. A. (1997), "Factors influencing a successful transition from ISO 9000 to TQM, the influence of understanding and motivation”, International Journal of Quality \& Reliability Management, Vol. 14, No. 2, pp. 100-117.

MORENO, M. D. (1993), “Training and the implementation of quality programmes by a sample of small and medium-sized firms in Spain”, Internatinal Journal of Quality \& Reliability Management, Vol. 10, No. 3, pp. 6-19.

NAJMI, M. and KEHOE, D. (2000), “An integrated framework for post-ISO 9000 quality development”, International Journal of Quality \& Reliability Management, Vol. 17, No. 3, pp. 226-258.

POWELL, T. C. (1995), “Total quality management as competitive advantage, a review and empirical study”, Strategic Management Journal, Vol. 16, No. 1, pp. 15-37.

PUNJ, G. and STEWART, D. (1983), "Cluster analysis in marketing research, review and suggestions for application”, Journal of Marketing Research, Vol. 20, No. 2, pp. 134-148.

QUAZI, H. A. and PADIBJO, S. R. (1998), “A journey toward total quality management through ISO 9000 certification - a study on small and medium-sized 
enterprises in Singapore”, International Journal of Quality \& Reliability Management, Vol. 15, No. 5, pp. 489-508.

RAHMAN, S. (2001), "A comparative study of TQM practice and organisational performance of SMEs with and without ISO 9000 certification", International Journal of Quality \& Reliability Management, Vol. 18, No. 1, pp. 35-49.

RAO, S. S.; RAGHUNATHAN, T. S. and SOLIS, L. E. (1999), "The best commonly followed practices in the human resource dimension of quality management in new industrializing countries. The case of China, India and Mexico”, International Journal of Quality \& Reliability Management, Vol. 16, No. 3, pp. 215-225.

SINGELS, J.; RUËL, G. and van de WATER, H. (2001), "ISO 9000 series certification and performance”, International Journal of Quality \& Reliability Management, Vol. 18, No. 1, pp. 62-75.

STEPHENS, K. S. (1994), “ISO 9000 and total quality”, Quality Management Journal, Fall, pp. 57-71.

TAYLOR, W. A. and MEEGAN, S. T. (1997), "Senior executives and the ISO 9000TQM transition”, International Journal of Quality \& Reliability Management, Vol. 14, No. 7, pp. 669-686.

Van der WIELE, A.; DALE, B. G. and WILLIAMS, A. R. T. (1997), "ISO 9000 series registration to total quality management, the transformation journey”, International Journal of Quality Science, Vol. 2, No. 4, pp. 236-252.

Van der WIELE, A; DALE, B. G. and WILLIAMS, A. R. T. (2000), "ISO 9000 series and excellence models: fad to fashion to fit”, Journal of General Management, Vol. 25, No. 3, pp. 50-66.

Van der WIELE, A; WILLIAMS, A. R. T. and DALE, B. G. (2000a), "ISO 9000 series registration to business excellence: the migratory path", Business Process Management Journal, Vol. 6, No. 5, pp. 417-427.

Van der WIELE, A; WILLIAMS, A. R. T. and DALE, B. G. (2000b), "Total quality management: is it a fad, fashion, or fit?”, Quality Management Journal, Vol. 7, No. 2, pp. 65-79.

WITHERS, B. E. and EBRAHIMPOUR, M. (1996), "An examination of ISO 9000 registration practices of American, German and Japanese firms operating in the USA”, International Journal of Quality \& Reliability Management, Vol. 13, No. 7, pp. 8-22.

YAHYA, S. and GOH, W-K. (2001), "The implementation of an ISO 9000 quality system”, International Journal of Quality \& Reliability Management, Vol. 18, No. 9, pp. 941-966. 
TABLES

Table I. Reasons for seeking certification according to the literature

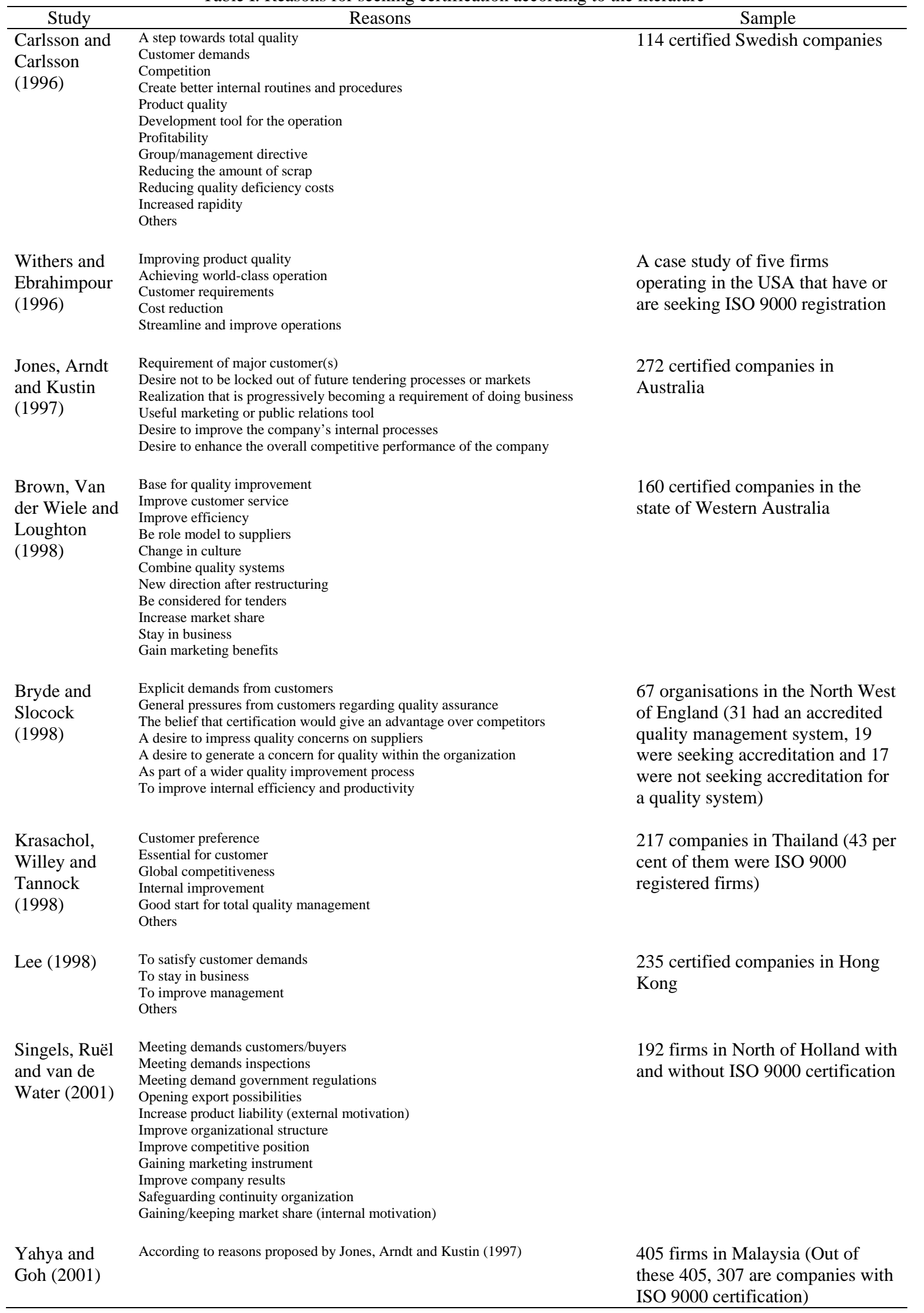


Table II. Reasons for seeking certification according to Spanish studies

\begin{tabular}{|c|c|}
\hline Casadesús, Giménez and Martí $(1998,1999)$ & Ferguson, Sánchez and Sierra (1999) \\
\hline Improving the quality image offered to the market & Improving process efficiency \\
\hline Customer requirements & Improving communication within the firm \\
\hline Improving the quality of the products and services offered & Improving product quality \\
\hline Consolidating and increasing market share & Increasing market share \\
\hline Improving the firm's efficiency and control & Improving relationships with employees \\
\hline Because it is a decision taken at a corporate level & Improving public image \\
\hline Because it is a good start towards total quality management & Demand from customers \\
\hline Reducing the number of faulty products & My competitors are ISO 9000 certified \\
\hline Martínez et al. (1999) & Escanciano, Fernández and Vázquez (2001) \\
\hline An initiative from the managerial team & Improving product/service quality \\
\hline Customer requirements & Improving internal process and procedures \\
\hline Suppliers requirements & Improving company image \\
\hline My competitors are ISO 9000 certified & Requisite to compete in the sector \\
\hline Stimulus from public bodies & Anticipating market trend, customer and competitors \\
\hline & Increase our competitive advantage \\
\hline & Use it as a promotional tool \\
\hline & Maintain/improve market share \\
\hline & Direct entrance to new markets \\
\hline & Corporate-level decision \\
\hline & Demand/pressure from customer \\
\hline & A basis for TQM \\
\hline & Cost reduction \\
\hline & My competitors are ISO 9000 certified \\
\hline
\end{tabular}

Table III. Number of certified firms according to number of employees

\begin{tabular}{lcccccccc}
\hline & \multicolumn{8}{c}{ Number of employees } \\
\cline { 2 - 9 } & \multicolumn{2}{c}{ Small } & \multicolumn{2}{c}{ Medium } & \multicolumn{2}{c}{ Large } \\
& $<20$ & $20-49$ & $50-99$ & $100-250$ & $>250$ & $>500$ & Total \\
\hline No. of firms & 17 & 17 & 27 & 24 & 8 & 13 & 106 \\
Total & & 34 & & \multicolumn{2}{c}{51} & 21 & 106 \\
Total (percentage) & & $32 \%$ & \multicolumn{2}{c}{$48 \%$} & $20 \%$ & $100 \%$ \\
\hline
\end{tabular}

Table IV. Reasons for seeking certification

\begin{tabular}{|c|c|c|c|}
\hline Reasons for seeking certification & Mean & Deviation & $\begin{array}{l}\text { Very important } \\
\% \text { Firms }\end{array}$ \\
\hline Improving the quality image offered to the market & 5.84 & 1.11 & 88.7 \\
\hline Improving the firm's control and efficiency & 5.80 & 1.21 & 84 \\
\hline Improving the quality of the products and services offered & 5.77 & 1.15 & 83 \\
\hline Belief that certification would give an advantage over competitors & 5.71 & 1.40 & 82.1 \\
\hline Desire to create a quality awareness in the firm & 5.61 & 1.21 & 82.1 \\
\hline Consolidating and increasing market share & 5.40 & 1.15 & 75 \\
\hline Reducing the number of faulty products & 5.13 & 1.38 & 67.9 \\
\hline Customer requirements & 5.05 & 2.00 & 64.2 \\
\hline Good start towards total quality & 4.66 & 1.49 & 53.8 \\
\hline
\end{tabular}


Table V. Rotated matrix of reasons for seeking certification

\begin{tabular}{lccc}
\hline \multicolumn{1}{c}{ Reasons } & Factor 1 & Factor 2 & Factor 3 \\
\hline Desire to create a quality awareness in the firm & 0.774 & & \\
Reducing the number of faulty products & 0.749 & & \\
Good start towards total quality & 0.683 & & \\
Improving the quality of the products and services offered & 0.653 & & -0.486 \\
Improving the firm's control and efficiency & 0.604 & 0.831 & \\
Belief that certification would give an advantage over competitors & & 0.721 & \\
Consolidating and increasing market share & & 0.617 & \\
Improving the quality image offered to the market & & & 0.838 \\
Customer requirements & 2.534 & 1.651 & 1.267 \\
\hline Eigenvalue & 28.155 & 18.341 & 14.077 \\
Percentage variance explained by factor & 28.155 & 46.496 & 60.573 \\
Percentage total variance explained & & & \\
\hline
\end{tabular}

Table VI. Importance of reasons for seeking certification

\begin{tabular}{llcc}
\hline & \multicolumn{1}{c}{ Factors } & Mean & Deviation \\
\hline Voluntary certification & External reasons & 5.6478 & 0.9940 \\
& Internal reasons & 5.3962 & 0.9121 \\
Compulsory certification & Customer requirements & 5.0472 & 1.9971 \\
\hline
\end{tabular}

Table VII. Agglomeration coefficient

\begin{tabular}{cccc}
\hline $\begin{array}{c}\text { Number of } \\
\text { groups }\end{array}$ & $\begin{array}{c}\text { Agglomeration } \\
\text { coefficient }\end{array}$ & $\begin{array}{c}\text { Percentage change } \\
\text { in the coefficient }\end{array}$ & $\begin{array}{c}\text { Differences between } \\
\text { percentage changes }\end{array}$ \\
\hline 10 & 87.417 & 10.98 & -0.85 \\
9 & 97.019 & 10.14 & -0.45 \\
8 & 106.853 & 9.69 & 6.05 \\
7 & 117.208 & 15.74 & -0.21 \\
6 & 135.659 & 15.53 & -1.03 \\
5 & 156.726 & 14.50 & 11.57 \\
4 & 179.446 & 26.06 & 6.17 \\
3 & 226.216 & 32.23 & 71.65 \\
2 & 299.128 & 103.88 & \\
1 & 609.863 & & \\
\hline
\end{tabular}

Table VIII. Factor averages and statistical tests showing differences

\begin{tabular}{lccccc}
\hline & \multicolumn{3}{c}{ Means } & \multicolumn{2}{c}{ Kruskal-Wallis } \\
\cline { 2 - 6 } Factors & Cluster 1 & Cluster 2 & Cluster 3 & Chi- & Sign. \\
$\mathrm{n}=47$ & $\mathrm{n}=38$ & $\mathrm{n}=21$ & square & \\
\hline Internal reasons & 5.8255 & 5.4632 & 4.3143 & 28.274 & 0.000 \\
External reasons & 5.9433 & 5.4474 & 5.3492 & 55.807 & 0.000 \\
Customer requirements & 6.0638 & 2.7368 & 6.9524 & 17.508 & 0.000 \\
\hline
\end{tabular}


Table IX. Contextual variables and statistical tests showing differences

\begin{tabular}{lccccc}
\hline & \multicolumn{3}{c}{ Means } & \multicolumn{3}{c}{ Kruskal-Wallis } \\
\cline { 2 - 6 } Contextual variables & Cluster 1 & Cluster 2 & Cluster 3 & Chi-square & Sign. \\
\hline Human elements & 5.3125 & 4.8784 & 4.7767 & 9.362 & 0.009 \\
Technical elements & 5.4643 & 5.2986 & 5.0008 & 9.819 & 0.007 \\
Progress towards TQM & 5.0851 & 4.7368 & 3.5714 & 15.067 & 0.001 \\
TQM performance & 5.4379 & 5.1391 & 5.1429 & 8.319 & 0.016 \\
\hline
\end{tabular}

Table X. Averages and statistical tests verifying the differences

\begin{tabular}{|c|c|c|c|c|c|c|c|c|}
\hline \multirow{3}{*}{ REASONS } & \multicolumn{4}{|c|}{ Size } & \multicolumn{4}{|c|}{ Industrial-servicies sector } \\
\hline & \multicolumn{2}{|c|}{ Levene's test } & \multicolumn{2}{|c|}{ ANOVA test } & \multicolumn{2}{|c|}{ Levene's test } & \multicolumn{2}{|c|}{ T test } \\
\hline & $\mathrm{F}$ & Sign. & $\mathrm{F}$ & Sign. & $\mathrm{F}$ & Sign. & $\mathrm{t}$ & Sign. \\
\hline Improving the firm's control and efficiency & 1.451 & 0.239 & 0.190 & 0.664 & 0.405 & 0.686 & 0.671 & 0.513 \\
\hline Improving the quality image offered to the market & 2.438 & 0.092 & 5.624 & 0.200 & 0.698 & 0.487 & 0.041 & 0.960 \\
\hline Good start towards total quality & 0.128 & 0.880 & 0.403 & 0.527 & -0.080 & 0.937 & 0.711 & 0.493 \\
\hline Reducing the number of faulty products & 0.010 & 0.990 & 0.27 & 0.871 & 0.812 & 0.418 & 0.345 & 0.709 \\
\hline Consolidating and increasing market share & 0.002 & 0.998 & 2.053 & 0.155 & 0.267 & 0.790 & 0.177 & 0.838 \\
\hline Desire to create a quality awareness in the firm & 1.168 & 0.315 & 2.655 & 0.106 & -1.579 & 0.117 & 0.417 & 0.660 \\
\hline $\begin{array}{l}\text { Belief that certification would give an advantage over } \\
\text { competitors }\end{array}$ & 2.012 & 0.139 & 0.134 & 0.715 & -0.786 & 0.434 & 0.197 & 0.821 \\
\hline
\end{tabular}

